\title{
AZ INTEGRÁCIÓ-SZEGREGÁCIÓ HELYZETE EGY KUTATÁS TÜKRÉBEN
}

\author{
Szerzők: \\ Laoues-Czimbalmos Nóra \\ Debreceni Egyetem (Magyarország) \\ Müller Anetta \\ Debreceni Egyetem (Magyarország) \\ Első szerző e-mail címe: \\ laoues.nora@ped.unideb.hu
}

Lektorok:

Bíró Melinda

Debreceni Egyetem (Magyarország)

Lenténé Puskás Andrea

Debreceni Egyetem (Magyarország)

Laoues-Czimbalmos Nóra és Müller Anetta (2018): Az integráció-szegregáció helyzete egy

kutatás tükrében. Különleges Bánásmód, IV. évf. 2018/4. szám, 19-31. DOI 10.18458/KB.2018.4.19

\begin{abstract}
Absztrakt
A múlt század utolsó éveitöl egyre jobban hangsúlyozzák a társadalmi integrációt az európai uniós állásfoglálások (UNESCO 1995; Európa 1998), vagyis szorgalmazzák, hogy a sajátos nevelési igényü gyermekek ne legyenek méltánytalanul megkülönböztetve társaiktól, kirekesztve társadalmi közegükböl (UNESCO 1995). Az integrált nevelést a közoktatásban az esélyteremtés, az esélyegyenlötlenségek csökkentésének eszközeként tekintik (Mesterházi, 2002).

Kutatásunkban integrált és szegregált intézményben nevelö-oktató pedagógusok $(n=86)$ kérdöives felmérésének eredményeit mutatjuk be az integráció kérdéskörével kapcsolatban, kiváncsiak voltunk arra, hogy mennyire befogadóak a szakemberek? Az eredmények azt mutatják, hogy a többségi iskolában tanitó pedagógusok jelentös hányada, részben ért egyet az integrált neveléssel- oktatással az adott válaszok alapján. Felkészültségüket mindkét intézményben tanitó pedagógusok, valamint gyógypedagógusok nem tartják megfelelönek, elegendőnek az integrált nevelés-oktatás megvalósitásához.
\end{abstract}

Kulcsszavak: integráció, szegregáció, fogyatékossággal élő személyek

Diszciplina: pedagógia, gyógypedagógia, szociológia

\begin{abstract}
Integration has been an international trend over the last two or three decades, the impact of which is increasingly evident in Hungary. EU resolutions emphasize social inclusion (UNESCO 1995, Europe 1998), ie advocating that children with special educational needs should not be unfairly discriminated against and excluded from society (UNESCO 1995). Integrated education in public education is a means of creating opportunities (Mesterházi, 2002).

In the integrated and segregated institution we present the results of a questionnaire survey of nursing teachers $(n=86)$ on the issue of integration, we were curious about how receptive the experts were. that a significant proportion of teachers in mainstream schools agree partly with integrated education on the basis of the responses given. Both their teachers and the
\end{abstract}


special educators they do not consider it appropriate, enough to implement integrated education.

Keywords: integration, segregation, people with disabilities

Disciplines: pedagogy, special education, sociology

A fogyatékos személyekkel és a megváltozott munkaképességü emberekkel kapcsolatban a befogadó szemlélet megjelenése hazánkban is új kihívásokat jelentett az oktatáspolitika területén is (Némethné, 2009).

Hazánkban évszázados hagyományai vannak a gyógypedagógiai intézményrendszernek, melyek a fogyatékossági típusok szerint diagnosztizáltak, azaz a fogyatékossági típus szerint külön oktatás során elégítette ki a sajátos nevelési igényeket (Gordosné, 2000).

Több szakirodalom definiálta és meghatározta már az inklúzió fogalmát, annak jelentéstartalmát (Csányi, 1990; Réthy, 2002; Papp, 2002). Vannak szakirodalmak, melyek a sajátos nevelési igényü tanulók integrált oktatásának módszertani aspektusaival foglalkoznak (Papp, 2002; Réthy, 2002, Csányi, 2008).

$\mathrm{Az}$ integrált nevelés hazai vonatkozásaival több szerző is foglalkozik. Az eltelt évtizedekben megvizsgálták a leendő tanítók és a már pályán lévő pedagógusok attitüdjét az integráció témájában, (Réti és Csányi, 1997) s azt tapasztalták, hogy a pedagógus társadalom hozzáállása negatív az integrációhoz. Az integrációról a kutatók által megkérdezett iskolavezetők, pedagógusok és fenntartók véleménye rendkívül megosztó. Kevesen osztják azt a véleményt, hogy az integráció pozitív hatású, szerintük bevezetésével nem változott semmi, de jelentős a számuk azoknak is, akik szerint több kárt okoz, mint hasznot (Balla, 2010).

Papp (2002) későbbi kutatási eredményei szintén hasonló eredményekkel zárult, aki az általános iskolai tanulásban akadályozott tanulók integrációját vizsgálta, kutatása azt az eredményt hozta, hogy a pedagógusok még felkészületlenek a feladatra. Véleménye szerint a helyzeten elsősorban az javítana, ha nem csupán a továbbképzések köre bővülne, hanem az alapképzésben kapna domináns helyet az együttnevelésre való felkészítés (Papp, 2004).

A társadalmi változások maguk után vonták a már meglévő csak még szundikáló nézetek felszínre törését, amelyek az együttérzésre, az emberi jogokra hivatkozva a fejlődés útjának a differenciáló, integráló oktatási eszközt tartják, mely jelen van a különböző célcsoportok nevelésében (Böddi és Keszei 2018; Horváth, Kiss és Szekeres, 2018; Lukács, 2016).

A társadalomnak egyik pillére, alrendszere az oktatás, mely meghatározza a következő generáció értékrendjét (Perlusz, 2013). Amilyen helyet foglal el az oktatás fontossági rendben a társadalomban úgy hat vissza rá. Az iskolák minősége, az oktatási rendszer szocializációs rendszere jelentősen befolyásolja a társadalmi folyamatokat, a különböző társadalmi csoportok esélyegyenlőségét (Bocsi, 2016; Bácsné, 2014, Kovács-Nagy 2017).

Az oktatás tehát a legalapvetőbb eleme az esélyteremtésnek. Nagyon fontos, hogy milyen szemlélet határozza meg működését, milyen az iskola nevelési-oktatási rendszere.

Országoként és koronként változik a sajátos nevelési igényü gyermekek szegregált vagy integrált nevelése. Most a tendencia a különböző okok együttes megjelenése miatt az együttnevelés, az integráció felé irányul (Köpatakiné, 2004).

Napjainkban egyre több szakirodalom fókuszál a fogyatékossággal élő emberek egészségére, életminőségére, melyben a szabadidős és sporttevékenységek, turisztikai szolgáltatások szerepe egyre jobban előtérbe kerül (Tatár et. al., 2018.a, 2018.b, Hidvégi et. al., 2018). 


\section{SZAKIRODALMI ÁTTEKINTÉS}

Demeter (2008), valós és átfogó képet fogalmazott meg az az integrált oktatásról. „Együtt vagy külön?” Az érvényben lévő oktatáspolitika célja az integráció támogatása, a pedagógiai folyamat hatékonyságának és sikerességének támogatása, illetve elméleti és gyakorlati pedagógusképzések szervezése. Demeter (2008) szerint az inkluzív nevelésben alapvető tényező a szemléletváltás mind a pedagógus, mind a szülő részéről is. Eredményképpen nő az esélyegyenlőség bíztatása, amelyet az Európai Unió tagállamai korábban közleményben is elfogadtak.

Ha az integráció alkalmazhatóságát hasonlítjuk a magyarhoz, találunk nagyon jó működő támogató példákat, különösen a skandináv országoknál (pl.: Dánia, Svédország), de számos európai országban felmerülnek akadályok, gondok a megvalósításban.

Chrissie R. (2007) Angliában végzett vizsgálata, egyértelmüen kijelenti, hogy a fogyatékos és ép gyermekek integrációja nem mindig pozitív hatást vált ki, főként az iskolák vezetőinél és pedagógusoknál. A szerző leszögezi, hogy nem a gyermekekkel és a szülökkel van gond, hanem a végrehajtó személyekkel, továbbá a fogyatékos gyerekek az együtt tanulás során szocializálódnak, de a tanulás eredményessége nem minden esetben felel meg az elvárásoknak. A szerző szerint minden nehézség, akadály ellenére is támogatják az integráció elvét és az együttnevelés megvalósítását.

A fogyatékossággal élő tanulók nevelése, oktatása, és szocializációjuk folyamatában számos fontos tennivaló ellátása, de valamennyi pedagógusnak közvetlenül és közvetve napi teendői közé tartozik a fogyatékosok ügye (Horváth, 2016; Mező és Mező, 2017). Feladatuk: többek között tudni a speciális segítségnyújtási lehetőségekről, meg kell tanítanunk az ép gyermekeket együtt élni a fogyatékossággal élő személyekkel, felismerni és megbecsülni értékes tulajdonságaikat, segíteni őket nehezített, hátrányos helyzetükben (Bocsi és Rákó, 2015).

Az integráció a nevelésben és a pedagógiában a fogyatékossággal élő és az ép egyének közös élet- és tanulási térben végbemenő együttnevelését, oktatását és képzését jelenti, ezáltal minden résztvevőnek optimális fejlődési lehetőséget biztosít (Réthy, 2002).

A támogató törvényi és pénzügyi háttér, a speciális eszközök, taneszközök megléte, a megfelelő osztálylétszám, a segítő szolgáltatások és személyek biztosítása mellett a sikeres integráció feltétele a módszertani, tanulásszervezési technikák ismerete és változatos használata és a legfontosabb tényezője a befogadó pedagógus (N. Tóth, 2011; Papp és Schiffer, 2011). Fontos a képzettség, a szociális érzékenység, a különbségek kezelésének képessége, differenciális szemlélete. Résztvevője a kedvező körülmények biztosításának, a kedvező tanulási környezet megteremtésének. Ha jó módszereket választ, jól tervezi a tananyag mennyiségét, egyéni fejlesztéssel, fejlesztő értékeléssel biztosítja a sajátos nevelési igényü tanulók kiegyensúlyozott fejlődését. Az inkluzív nevelés kihívás, befogadó nevelőtestületben lesz eredményes (Baloghné Bakk, 2012).

A fentiekből tapasztaltak alapján kijelenthetjük, hogy mindenképpen érdemes tanulmányozni és vizsgálni az iskolai integráció kérdéskörét. A végzett felmérések között még nem terjedt el széles körben specifikusan az együttnevelés, illetve inkluzivitás probléma körének kutatása.

\section{Módszer}

Kíváncsiak voltunk, hogy napjainkban hogyan alakult, illetve hogy változott-e a helyzet az inkluzív nevelés pegadógusok körében történő megítélése kapcsán? A kutatásunkhoz kérdöíves vizsgálatot választottunk.

A kutatásunk előtt az alábbiakra kerestük a választ:

- Hogyan valósul meg az integráció /inkluzió a többségi iskolában? 
- Milyen feltételei vannak megvalósulásnak?

- Milyen tényezők befolyásolják a pedagógusokat az integráció kérdésében?

- Különbözik-e az integráló és nem integráló iskolák pedagógusainak véleménye?

Hipotézis:

- A többségi intézmények pedagógusai nem tartják elegendőnek felkészültségüket az integrált nevelés-oktatás megvalósításához.

- Jobb személyi és tárgyi feltételek mellett a többségi általános iskolában tanítók szívesebben vállalják a sajátos nevelési igényü tanulók együtt nevelését-oktatását ép társaikkal.

- Igénylik a gyógypedagógiai intézményben tanítók az integrációt.

\section{Minta}

A kutatásunkat kéttípusú köznevelési-oktatási intézményben végeztük Szabolcs-SzatmárBereg megyében, ahol összesen 90 pedagógussal töltettük ki a kérdőívet, melyből $86 \mathrm{db}$ volt teljesen kitöltött, értékelhető. Az egyik integrált intézmény 46\% (40 fó), a másik pedig szegregált intézmény 54\% (46 fö) volt, melyben a kutatást végeztük (lásd: 1. ábra).

1. ábra: A válaszadók megoszlása (Forrás: a Szerzők)

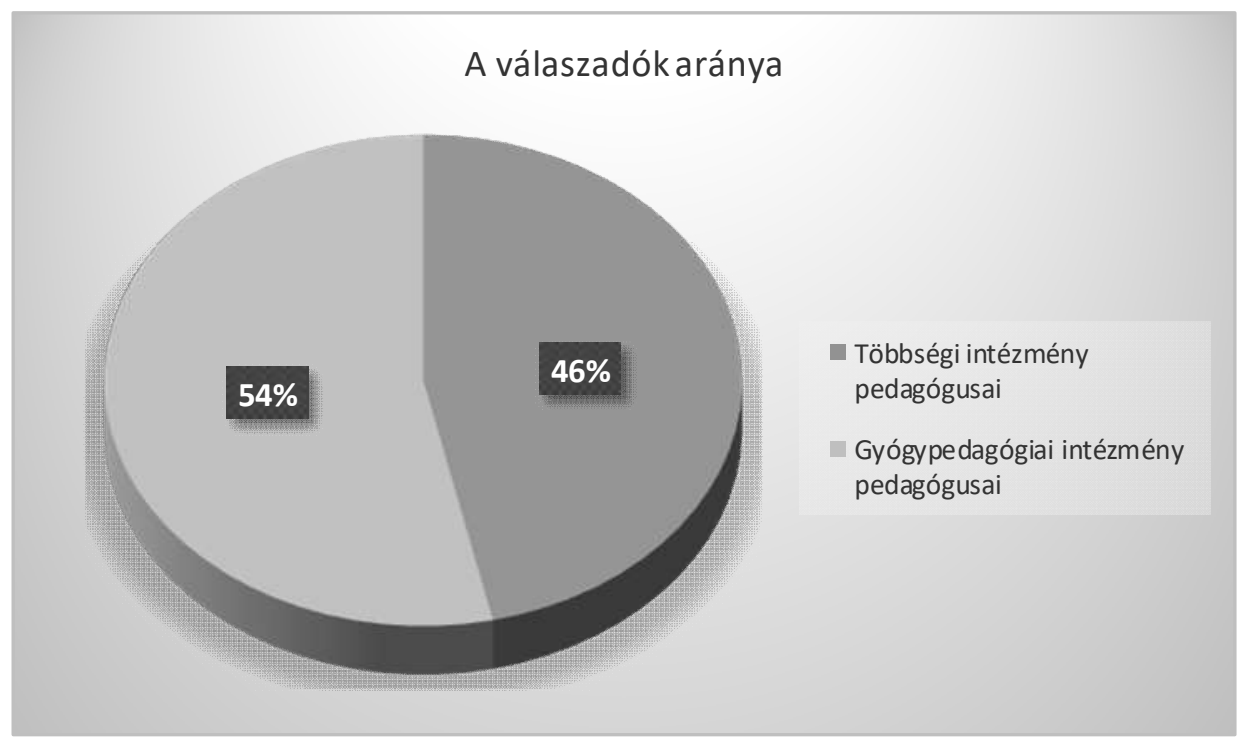

\section{A válaszadók iskolai végzettsége}

A megkérdezett többségi pedagógusok körében tanárképző és gyógypedagógiai főiskolai végzettsége 4\%-nak van. A gyógypedagógusok körében ez az arány 18,1\%. Mindössze 5 fö olyan pedagógus $(15,2 \%)$ van a gyógypedagógiai iskolában, akinek még nincs gyógypedagógiai végzettsége. A túlnyomó többség 24 fő $(85,7 \%)$ ilyen végzettséggel rendelkezik (lásd: 1. táblázat). 
1. táblázat: A válaszadók iskolai végzettsége (Forrás: a Szerzök)

\begin{tabular}{|c|c|c|c|c|c|c|}
\hline \multirow{2}{*}{$\begin{array}{c}\text { Iskolai } \\
\text { végzettség }\end{array}$} & \multicolumn{3}{|c|}{ Többségi intézmény pedagógusai } & \multicolumn{3}{c|}{ Gyógypedagógiai intézmény pedagógusai } \\
\cline { 2 - 7 } & $\begin{array}{c}\text { Tanárképzö } \\
\text { Főiskola }\end{array}$ & $\begin{array}{c}\text { Gyógypedagógia } \\
\text { i Föiskola }\end{array}$ & Mindkettő & $\begin{array}{c}\text { Tanárképzö } \\
\text { Főiskola }\end{array}$ & $\begin{array}{c}\text { Gyógypedagógiai } \\
\text { Főiskola }\end{array}$ & Mindkettö \\
\hline $\begin{array}{c}\text { Százalékos } \\
\text { arány }\end{array}$ & $85,7 \%$ & $10,3 \%$ & $4 \%$ & $15,2 \%$ & $66,7 \%$ & $18,1 \%$ \\
\hline Összesen: & \multicolumn{3}{|c|}{$100,0 \%$} & & $100,0 \%$ & \\
\hline
\end{tabular}

\section{Eszközök}

A kérdőívben zárt és nyílt kérdéseket is alkalmaztunk. A pedagógusokat válaszkategóriákkal is segítettük. Az adatokat Excel adatbázis segítségével dolgoztuk fel, az eredményeket grafikusan is ábrázoltuk.

A válaszadók közül nők és férfiak is képviseltették magukat a mintában $(n=86)$. A vizsgálatban kéttípusú köznevelési-oktatási intézményt néztünk meg.

Az integrált többségi intézmény pedagógusai közül a férfiak 23\%-a (9 fö), a nők 77\%-a (31 fö) adott választ, a gyógypedagógiai intézményben dolgozó pedagógusok nemek aránya a következő szerint alakult a férfiak 14\% (6 fö), a nök 86\% (40 fö). Az eredményeket az 2. ábra szemlélteti.

2. ábra: A válaszadók nemek aránya (Forrás: a Szerzők)

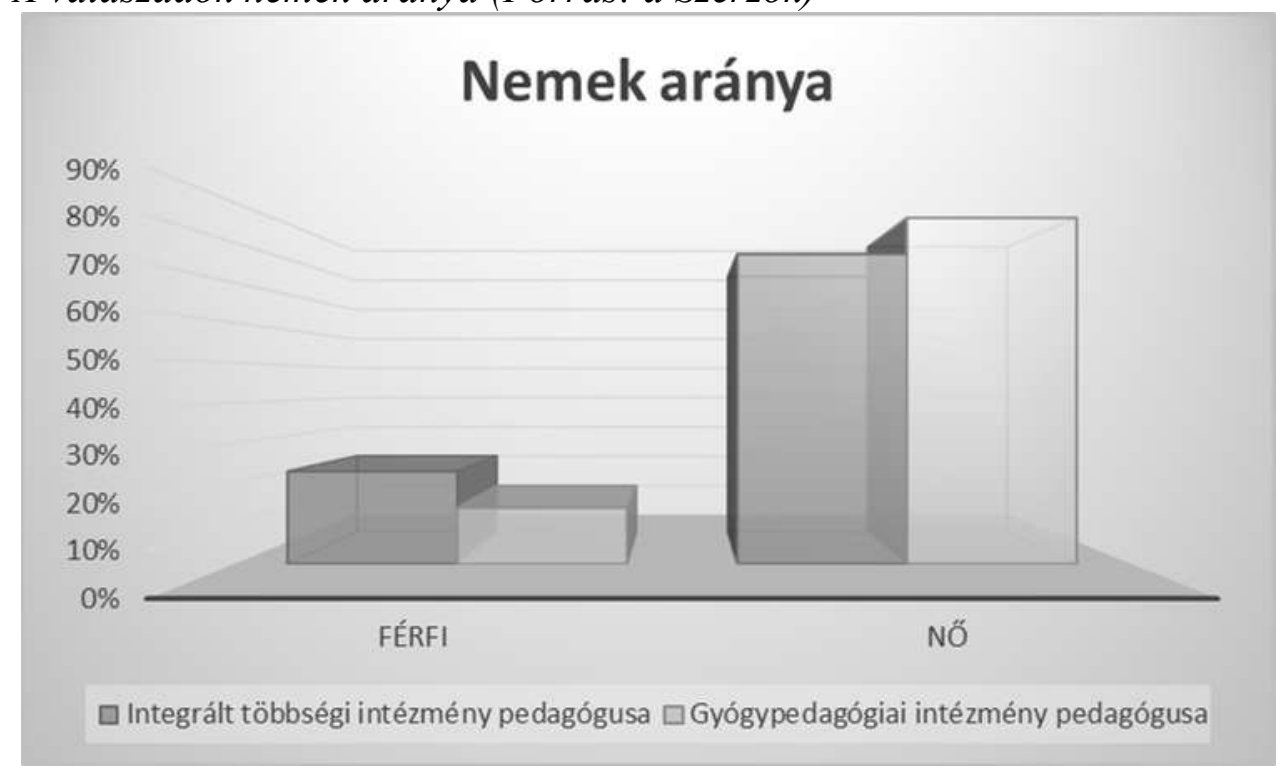

\section{Eredmények}

A válaszadók véleménye az integrációról

Alapvető emberi jog, minden embert megillet, a többségi pedagógusok 14,3\%- a választotta ezt az állítást, míg a gyógypedagógusok $22 \%$-a, amely - ezek az adatok igen ,beszédesek”azt tükrözi, hogy az integráció körükben jobban elfogadott, de így is kisebbségben levő vélemény a részbeni egyetértés adatai is tükrözik (lásd: 2 . táblázat).

Az integráció alkalmazásával részben ért egyet:

- Többségi pedagógus $42,9 \%$

- Gyógypedagógusok 29,3\%

Az intézmények feltételeinek minőségéről, szinte azonosan vélekednek:

- Többségi pedagógus $42,8 \%$

- Gyógypedagógus 48,7\% 
2. táblázat: A válaszadók véleménye az integrációról (Forrás: a Szerzök)

\begin{tabular}{|l|c|c|c|c|}
\hline $\begin{array}{l}\text { Vélemények az } \\
\text { integrációról }\end{array}$ & $\begin{array}{c}\text { Alapvetö } \\
\text { emberi jog, } \\
\text { minden ember } \\
\text { megillet }\end{array}$ & $\begin{array}{c}\text { Nem minden esetben } \\
\text { értek egyet } \\
\text { alkalmazásával }\end{array}$ & $\begin{array}{c}\text { A speciális integráció } \\
\text { sokkal jobb feltételeket } \\
\text { biztosítana az SNI } \\
\text { tanulóik számára }\end{array}$ & Összesen \\
\hline $\begin{array}{l}\text { Többségi } \\
\text { intézmény } \\
\text { pedagógusai }\end{array}$ & $14,3 \%$ & $42,9 \%$ & $42,8 \%$ & $100,0 \%$ \\
\hline $\begin{array}{l}\text { Gyógypedagógiai } \\
\text { intézmény } \\
\text { pedagógusai }\end{array}$ & $22 \%$ & $29,3 \%$ & $48,7 \%$ & $100,0 \%$ \\
\hline
\end{tabular}

Az integráció megvalósitásának feltételeinek megléte

A megkérdezett pedagógusok az integráció megvalósításának feltételeinek meglétéről az 3. ábra szemlélteti.

3. ábra: A válaszadók véleménye az integráció megvalósitásának feltételeiről (Forrás: Szerzök)

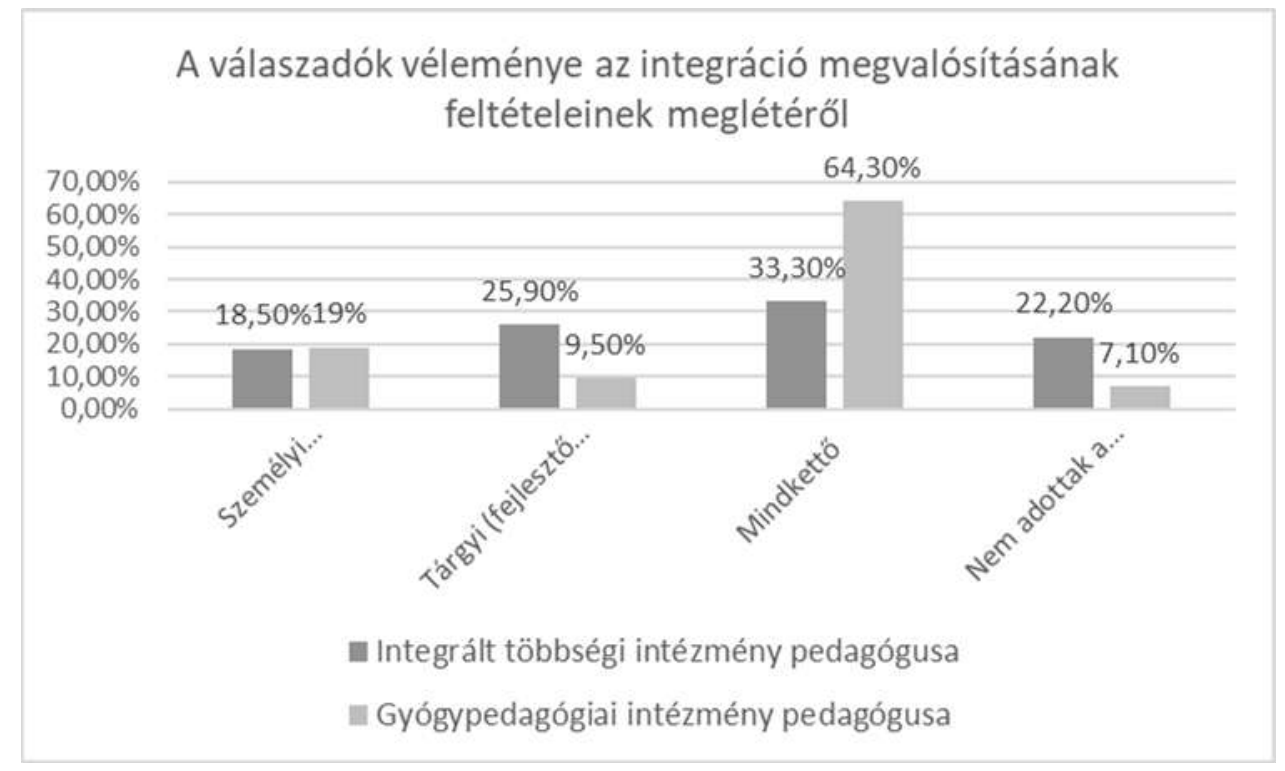

A válaszadók véleménye a sajátos nevelési igényü tanulók befogadásával kapcsolatban

Az integrációról alkotott vélemények feltérképezése mellett arra is kitért a felmérés, hogy milyen véleménnyel vannak a megkérdezettek az integráció megvalósításának feltételeiről, milyen tapasztalataik vannak az alábbi tényezőkről a saját intézményükben:

személy feltételekről alkotott vélemények a pedagógusok körében a következőképpen alakultak: a többségi intézményben dolgozó pedagógusok 18,5\%-a, a gyógypedagógiai intézményben dolgozó tanárai 19\%-a válaszolta azt, hogy a személyi feltételek adottak az integráció megvalósításához a saját intézményükben. A tárgyi feltételek meglétéről a többségi intézmény pedagógusai $25,9 \%$-a hiányolja a szükséges tárgyi feltételek meglétét, a gyógypedagógusok körében, 9,5\% elégedetlen a tárgyi feltételekkel saját intézményében. Arra a kérdésre, hogy minkettő feltétel (személyi és tárgyi) adott az integráció megvalósításához a vélekedések, mindkét iskola típusnál adottak mind a személyi mind a tárgyi feltételek, az eredmény azt tükrözi, hogy a gyógypedagógiai intézményben jobbak és adottak a feltételek, mivel érthető és feltételezhető hogy, egy speciális intézményröl van szó. 
Összeségében megállapítható, hogy a többségi iskolában dolgozó pedagógusok 22,2\%-uk hiányolja a személyi és tárgyi feltételeket, míg a gyógypedagógiai dolgozó pedagógusai $7,1 \%$-uk.

A előzőeket alátámasztja Havas (2006), aki szerint időszerü probléma, hogy az iskolai szegregációval gyakran együtt jár a tárgyi feltételek és a pedagógiai munka, valamint a pedagógiai szolgáltatások átlagoshoz viszonyított lényegesen alacsonyabb színvonala.

A megkérdezettek véleménye a sajátos nevelési igényű tanulók befogadásával kapcsolatban a többségi iskolában dolgozó pedagógusai többségében „negatív” válaszokat adott 57,1\%, a szegregált intézményben dolgozó pedagógusoknál ez az érték csak 10,8\%.

Jelentős a különbség, ebből is látható, hogy a gyógypedagógusok szép száma vélekedik pozitívan $(89,2 \%)$ a sajátos nevelési igényü tanulók befogadásával kapcsolatban. A „többségi” pedagógusok (42,9\%) esetén, viszont mondhatjuk, hogy hiányosak a megfelelő módszertani ismeretek (Lásd: 3 . táblázat).

3. táblázat: A válaszadók véleménye az Sajátos nevelési igényü tanulók befogadásával kapcsolatban (Forrás: Szerzök)

\begin{tabular}{|l|c|c|}
\hline $\begin{array}{c}\text { A megkérdezettek } \\
\text { válaszai }\end{array}$ & $\begin{array}{c}\text { Többségi } \\
\text { intézmény pedagógusainak } \\
\text { válaszai }\end{array}$ & $\begin{array}{c}\text { Gyógypedagógiai intézmény } \\
\text { pedagógusainak válaszai }\end{array}$ \\
\hline Pozitív & $42,9 \%$ & $89,2 \%$ \\
\hline Negatív & $57,1 \%$ & $10,8 \%$ \\
\hline Összesen: & $100,0 \%$ & $100,0 \%$ \\
\hline
\end{tabular}

\section{A válaszadók véleménye az integrációról az ép gyerekek szemszögéböl}

A válaszadók véleményeik az integrációról az ép gyerekek szemszögéből „pozitív” vélemények a többségi pedagógusoknál 40,7\%, gyógypedagógiai intézményben dolgozó pedagógusoknál 54,1\%, a „,negatív” vélemények pedig a többségi pedagógusoknál 59,3\%, gyógypedagógusoknál 45,9\% (Lásd: 4. táblázat).

Összeségében elmondható, hogy a válaszadók többsége ebben a kérdésben másképp vélekedett, a gyógypedagógiai intézményben dolgozó pedagógusoknál jelentősen jobb az arány, de itt is elmarad a teljes azonosulástól.

A többségi pedagógusoknál esetleg visszavezethető a helytelen kivitelezésre, elökészítésre, a felkészületlenségre, személyi és tárgyi feltételek hiányára.

4. táblázat: A válaszadók véleménye az integrációról az ép gyerekek szemszögéböl (Forrás: Szerzők)

\begin{tabular}{|l|c|c|}
\hline $\begin{array}{c}\text { A megkérdezettek } \\
\text { válaszai }\end{array}$ & $\begin{array}{c}\text { Többségi } \\
\text { intézmény pedagógusainak } \\
\text { válaszai }\end{array}$ & $\begin{array}{c}\text { Gyógypedagógiai intézmény } \\
\text { pedagógusainak válaszai }\end{array}$ \\
\hline Pozitív & $40,7 \%$ & $54,1 \%$ \\
\hline Negatív & $59,3 \%$ & $45,9 \%$ \\
\hline Összesen: & $100,0 \%$ & $100,0 \%$ \\
\hline
\end{tabular}


A válaszadók véleménye egy bemutatott képröl

A felmérésben egy bemutatott kép alapján kellett a mindkét intézmény típusban tanító pedagógusoknak válaszolni arra a kérdésre, hogy „Mi jut eszébe a képről? (lásd: 4. ábra).

5. ábra: A válaszadók véleménye egy bemutatott képröl (Forrás: Net 1)

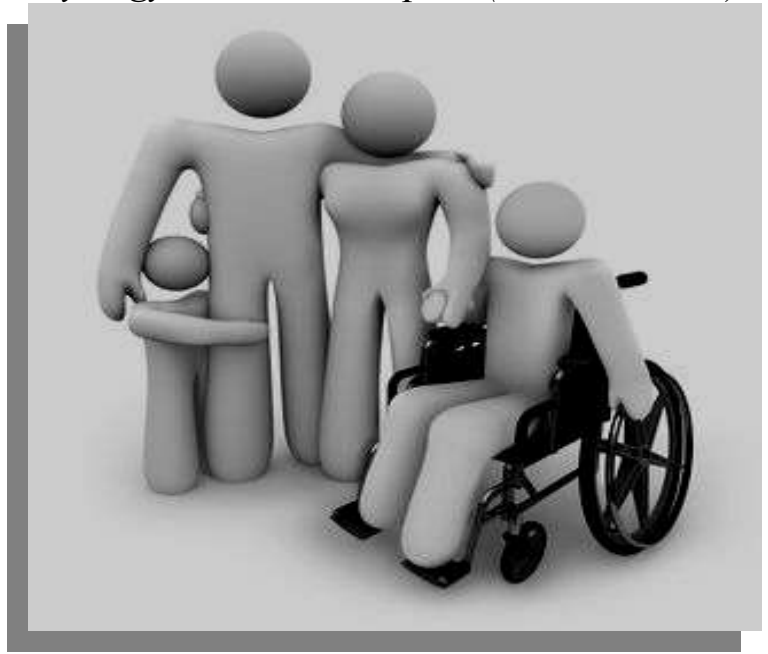

Az alábbi tényezőkre lehetett választ adni, amelyekre a következőképpen alakultak:

Az eredményeket az 5. ábra szemlélteti.

- Érdekes: mind a többségi és a gyógypedagógusok körében $0 \%$

- Elgondolkoztató: többségi pedagógusok 23,5\%, gyógypedagógusok 23,1\%

- Szívet melengető: többségi pedagógusoknál 32,4\%, gyógypedagógusoknál 30,8\%

- Elismerést kiváltó. többségi pedagógusoknál 44,1\%, gyógypedagógusoknál 46,2\%

- Megbotránkoztató: mindkét két pedagógusoknál 0\%

Igazán fontos a pedagógusok attitüdje szempontjából. Nincs elutasítás, és az elgondolkodtató választ adók is remélhetően a tennivalókat veszik sorra. Mindkét intézménytípusban közel azonos a válaszok megoszlása.

6. ábra: A válaszadók véleménye a bemutatott képröl (Forrás: Szerzők)

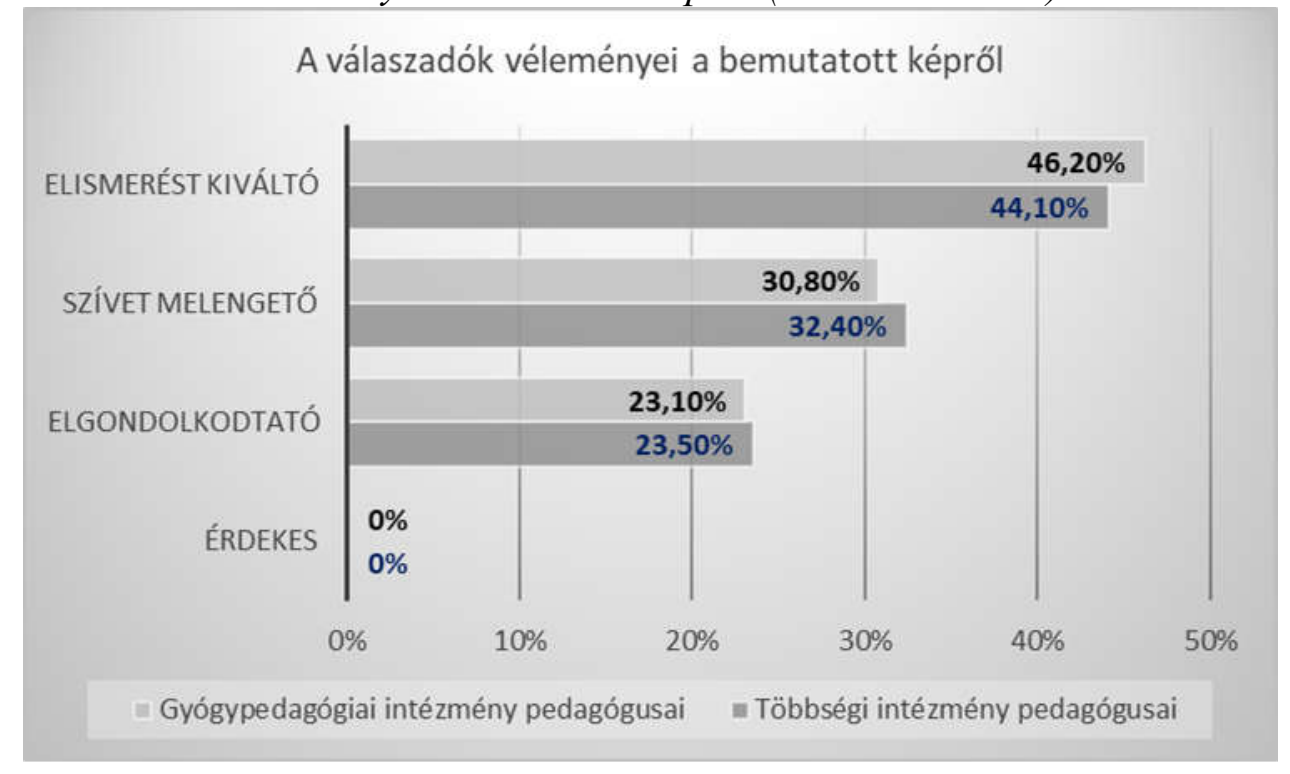


A megkérdezettek válaszai az integrációval kapcsolatos képzésekröl

A vizsgálatnál rá kérdeztünk az integrációval kapcsolatos képzések részvételi szándékaikról a többségi iskola pedagógusa 53,8\%-a, gyógypedagógiai iskolában dolgozó pedagógusa 74,3\%-a részt vett valamilyen integrációval kapcsolatos képzéseken. A „nem vett részt" válaszoknál, a többségi iskola pedagógusa 46,2\%, a szegregált intézményben dolgozó pedagógusa $25,7 \%$.

A gyógypedagógiai intézményben sokkal jobb az arány. Tehát, a többségi iskolában fontos feladat a továbbképzések számának növelése (lásd: 6. ábra).

7. ábra: A megkérdezettek válaszai az integrációval kapcsolatos képzések részvételi szándékaikról (Forrás: Szerzők)

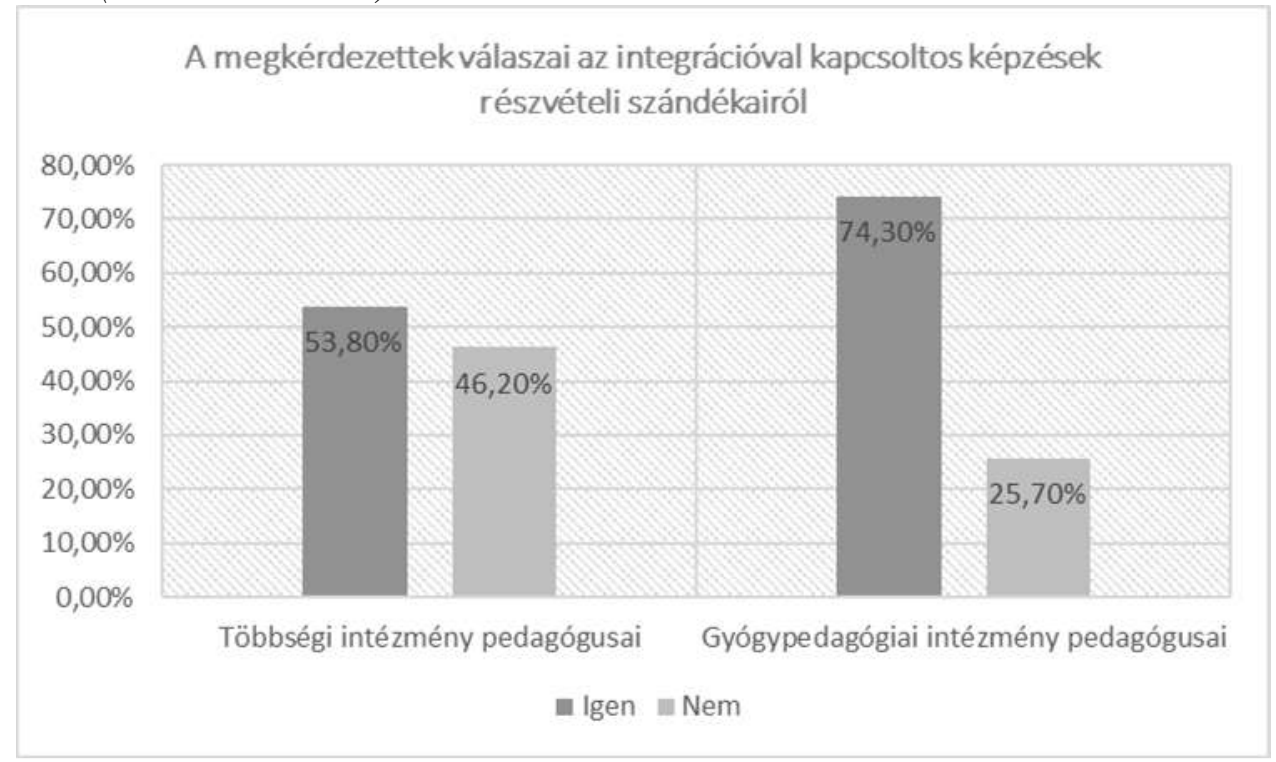

A pedagógusok felkészültsége az integrált nevelésre-oktatásra

Az eredményeket a 7. ábra szemlélteti.

A többségi pedagógusoknál 3,8\%-uk, gyógypedagógiai iskolában dolgozó pedagógusok 48,6\%-uk vélekedik arról, hogy „teljesen felkészült” az integrált nevelésre-oktatásra. A „részben felkészültek” aránya a többségi pedagógusoknál 96,2\%, gyógypedagógiai intézményben dolgozó pedagógusoknál 51,4\%.

Összességében az tapasztalható, hogy a többségi pedagógusok önmaguk is látják felkészültségük hiányát $6,2 \%$, a gyógypedagógiai intézményben dolgozó pedagógusoknak viszont sokkal jobb a továbbképzési arány, mégis érzik a további ismeretek szükségességét $51,4 \%$.

A jól végzett integrációs tevékenység nagy felkészültséget, tapasztalatot, többletmunkát kíván. Csak kevesen vannak, akik nem látják az együttnevelés hasznosságát, vagy nem gondolják, hogy pozitív hatásai lehetnek a törekvésnek.

Fontos a befogadó intézmények pedagógusainak támogatása, segítése, hitének erősítése az integráció iránt.

Fontos, hogy az iskolák tisztában legyenek az integrációval, ismerjék a nemzetközi tapasztalatokat, munkájuk elkötelezettségének tudatával tanítsanak. 
8. ábra: A válaszadók felkészültsége az integrált nevelésre-oktatásra (Forrás: Szerzők)

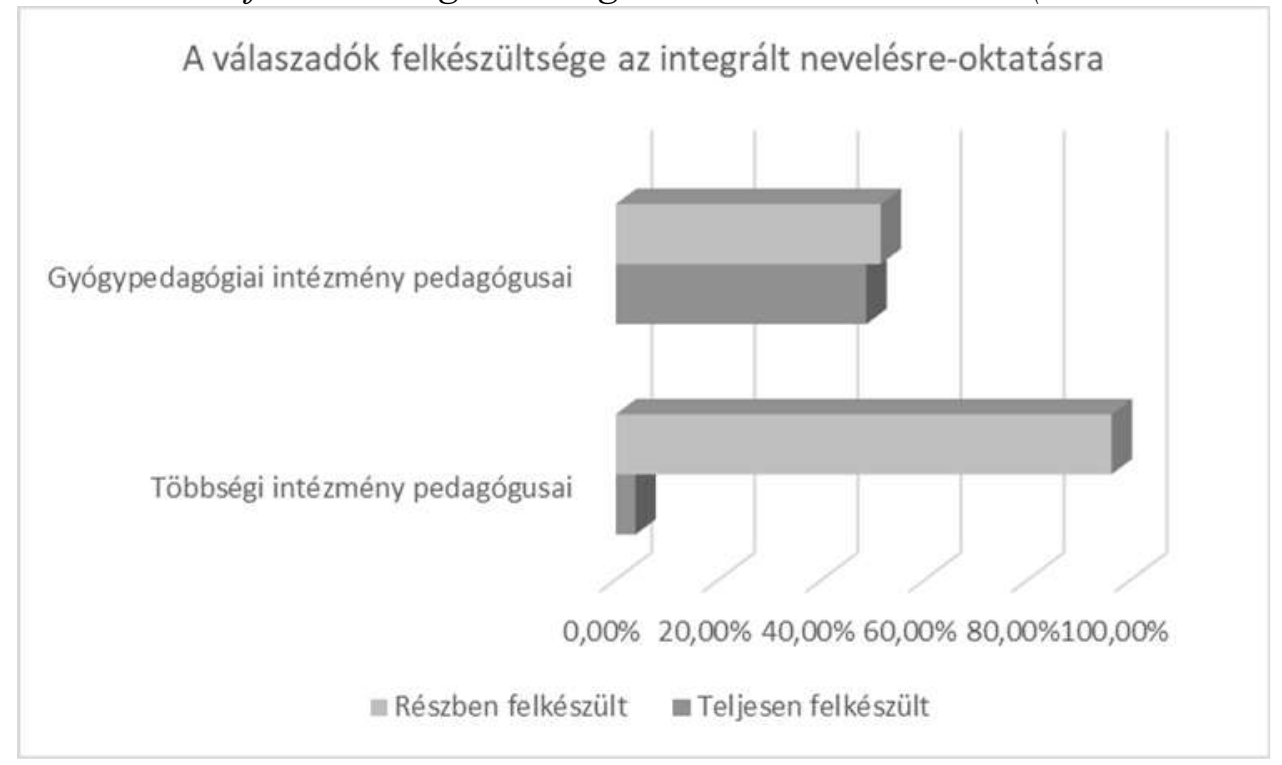

\section{Megvitatás}

Az integráció kérdésében a felmérések alapján arra a megállapításra jutottunk, hogy széleskörü társadalmi, ezen belül a pedagógus társadalom összefogására van szükség.

A pedagógusok és a szülők, fokozottabb tájékoztatása szükséges ahhoz, hogy megvalósulhasson a többségi és a gyógypedagógiai intézményekben a sajátos nevelési igényü tanulók együtt nevelése-oktatása.

Ennek érdekében javítani kell a személyi és tárgyi feltételeken a Szakbizottságok munkáját még hatékonyabban meg kell ismertetni a szülőkkel és a pedagógusokkal. Átjárhatóság (hospitálás) mindkét oktatási intézményben, Ugyan is a gyógypedagógiai intézmények jelenleg szegregáltan müködnek. Ennek egyik oka lehet, hogy az ott tanítók féltik tanítványaikat és állásukat is az integráció hatásától.

\section{Korlátozások}

A kutatás korlátai között említhetjük, hogy kis elemszámú mintán történt a kutatás. Ez azonban olyan irányokat és tendenciákat mutat, mely érdemessé teszi a kutatást egy nagyobb elemszámú mintán való kiterjesztését.

\section{Konklúziók}

A többségi pedagógusok jelentős hányada, részben ért egyet az integrált neveléssel oktatással az adott válaszok alapján. Felkészültségüket mindkét intézményben tanító pedagógusok nem tartják megfelelőnek, elegendőnek az integrált nevelés-oktatás megvalósításához.

Az integráció megvalósulása függ a személyi és tárgyi feltételektől, ha ezek megfelelő mértékben adottak lesznek, a többségi általános iskolában tanító pedagógusok szívesen vállalják a sajátos nevelési igényü tanulók együtt nevelését-oktatását ép társaikkal.

Azok a gyerekek, akik bizonyos területeken fogyatékossággal élnek, illetve akadályozottak, érzékenyebbek, de érzelmileg sokkal gazdagabbak. Számukra így kerek a világ. Ha befogadjuk őket és segítjük, csodákra képesek az élet minden területén. A közös munka során kölcsönösen hatunk egymásra. 
Az ép gyermekek szemszögéből az integráció azért érték, mert megtapasztalhatják sérült társaik emberi mivoltát, az együtt-, egymás mellett élés örömeit, buktatóit. Ha már egészen kicsi koruktól együtt nevelődnek, akkor valószínüsíthető, hogy felnőtt korukban sem fogják elítélni, kirekeszteni őket a társadalomból.

A sajátos nevelési igényü gyermekek szemszögéből fontos a naponta megkapott pozitív modell mellett a szakszerü, sérülésspecifikus fejlesztés, és ezek által személyiségük, képességeik minél teljesebb kibontakoztatása.

A felnőttek szemszögéből az integráció azért érték, mert megélheti: egy sajátos érzelmi kapcsolatrendszer kialakulását, fejlődését, a gyermekekért - épért és fogyatékosért egyaránt való tevés örömét, az értük érzett felelösség vállalását.

Az integrációnak éppen a társadalmi egyenlőségre való törekvés a lényege. Csak akkor tud az integrációfejlesztő hatással rendelkezni, ha megvan a megfelelö együttmüködés (megértés és bizalom) a szülő - a pedagógus - az integráló intézmény között. Nagyon fontos, hogy a pedagógusok folyamatosan képezzék magukat, olyan szakmai ismeretekkel rendelkezzenek, hogy bármikor fogadni tudják az akadályozott gyermeket.

$\mathrm{Az}$ iskola minőségi müködése alapvetően a pedagógusokon múlik. A pedagógusok elkötelezettségének mértéke, személyiségük, pedagógiai kultúrájuk milyensége nagyban befolyásolja az intézményt céljai elérésében. Ezeket a célokat az oktatási rendszert is magába foglaló nagyobb rendszer céljai, a társadalmi, környezeti célok befolyásolják. Ennek egyféleképp tud megfelelni az oktatás, ha olyan embereket bocsát ki a falai közül, akik használható tudással, erős, de rugalmas személyiséggel, és a folyamatos tanulás képességével, a tanulni tudással rendelkeznek. Nagyon fontos, hogy a nevelötestület minden tagja támogassa az integráció gondolatát. Az integrációt vállaló pedagógusokat ne hagyják magukra, szervezett formában készülhessenek erre a feladatra, munkájukat folyamatosan segítsék a szakemberek. A pedagógiai többletteljesítményeket értékeljék, és megfelelő módon díjazzák.

A sikeres együttnevelés a záloga a későbbi, természetes társadalmi együttélésnek. A szemléletformálást már a pedagógusképzésben kellene kezdeni. Ha a pedagógusnak fontos a közösség, a demokrácia, a jogok és a másik ember tiszteletben tartása, így is nevel. Az integrációra igen alkalmas a sport, mely képes ennek a befogadó szemléletnek a megvalósítására (Gál et. al. 2014).

A publikáció elkészitését az EFOP-3.6.2-16-2017-00003 számú projekt támogatta. A projekt az Európai Unió támogatásával, az Európai Szociális Alap társfinanszírozásával valósult meg.

\section{IRODALOM}

Bácsné, Bába É. (2014): Kisgyermekes anyák a munkaerőpiacon - pro és contra. Taylor: Gazdálkodás- és Szervezéstudományi Folyóirat: A Virtuális Intézet Közép-Európa Kutatására Közleményei 6, 1-2. 250-259.

Balla, I. (2010): Mi lesz a cigánygyerekekkel? (letöltés: 2018.08.26) (Web: https://bit.ly/2zzvOVh).

Baloghné Bakk A. (2012): Soproni óvodapedagógus hallgatók felkészültségének vizsgálata a fogyatékossággal élő gyermekek együttnevelésére. In: Varga, L. (szerk.) 6. Képzés és Gyakorlat Nemzetközi Neveléstudományi Konferencia: Humántudományi kutatások a pedagógusképzés szolgálatában: Generációk találkozása. Sopron, Magyarország: Nyugat-magyarországi Egyetem Kiadó. 125-126. 
Bocsi V., Rákó E.(2015): A sajátos nevelési igényü gyermekek integrált nevelése mint a tanári pálya egy lehetséges kimenete. In: Szilágyi, B., Mező, K., Mezö, F. (szerk.) $A z$ együttnevelés útjai. Debrecen, Magyarország: Debreceni Egyetemi Kiadó, 205-216.

Bocsi, V. (2016): Motivációk, célok és elképzelések. Roma fiatalok oktatással kapcsolatos tervei. In: Semsei, Imre; Kovács, Klára (szerk.) Inkluzív nevelés - inkluzív társadalom, Debreceni Egyetemi Kiadó, Debrecen. 9-32.

Böddi, Zs., Keszei, B. (2018): Integrált óvodai csoportba járó sajátos nevelési igényü gyermekek interakcióinak feltárása a természetes megfigyelés módszerével. In: Lippai, E. (szerk.) Változás az állandóságban: A Magyar Pszichológiai Társaság XXVII. Országos Tudományos Nagygyülése: Kivonatkötet. Budapest, Magyar Pszichológiai Társaság, 232-233.

Chrissie Rogers (2007): Parenting and Inclusive Education. Discovering Difference, Experiencing Difficulty. Palgrave Macmillan UK.

Csányi, Y. (1990): Fogyatékosok integrációja- nemzetközi és hazai kitekintés. Gyógypedagógiai Szemle, 4, 271-279.

Csányi, Y. (2008): Új utak és törekvések a sajátos nevelési igényü személyek oktatása terén az OECD szakmapolitikájában és ennek néhány hazai vonatkozása. Fejlesztö pedagógia, 1. 28-33.

Demeter, J. (2008): Együtt vagy külön? Gondolatok és valós képek az együttnevelésről. TaníTani,2.

Europe (1998): The education systems in member states: Chapter 10, Special education. European Agency for Special Education (Letöltés: 2018.05.30.) (Web: https://bit.ly/2DJ4OVZ).

Gál, A. Dóczi, T. Sáringerné, Sz. Zs. (2014):Társadalmi befogadás a sportban és a sport által (szociális inklúzió). Budapest, Magyarország: Magyar Sporttudományi Társaság, Magyar Sportmenedzsment Társaság.

Gordosné Szabó A. (2000): A gyógypedagógiai iskoláztatás fejlődése. In: Illyés S.(szerk.): Gyógypedagógiai alapismeretek. ELTE BGGYFK, Budapest. 333-356.

Havas, G. (2006): Ó, ió, ció, szegregáció. Módszertani segédanyag (Letöltés: 2018.09.15.)(Web: https://bit.ly/2BxXifj).

Hidvégi, P., Bíró, M., Lenténé, P.A., Pucsok, J. M., Tatár, A. (2018): Fogyatékkal élők turizmusának lehetőségei az észak-alföldi régióban. In: Válogatott tanulmányok a sporttudományok köréből. Debreceni Egyetem Sporttudományi Koordinációs Intézet, Debrecen. 158-164.

Horváth E., Kiss D., Szekeres Á. (2018): Új lehetőségek a társas kapcsolatok kialakítására sajátos nevelési igényü tanulók integrált nevelésében In: Karlovitz, János T. (szerk.) $V$. Neveléstudományi és Szakmódszertani Konferencia [Vzdelávacia, výskumná a metodická konferencia]: Program és tartalmi összefoglalók. Komárno, Szlovákia : International Research Institute, 38-38.

Horváth, L. (2016): Az inklúzió megközelítése a fogyatékosság és társadalom kapcsolatában In: Semsei, Imre; Kovács, K. (szerk.) Inkluzív nevelés - inkluzív társadalom. Debrecen, Debreceni Egyetemi Kiadó. 53-85.

Kovács, K. E., Nagy, B. E. (2017): Kockázati magatartás a különböző szerkezetü családokban, In: Mrázik Julianna (Szerk.) A tanulás új útjai. Budapest: Magyar Nevelés- és Oktatáskutatók Egyesülete (HERA), 647-664.

Kőpatakiné, Mészáros M. (2004): Közben felnő egy elfogadó nemzedék. Új Pedagógiai Szemle 2, 38-48.

Lukács, Sz. (2016): Újraértelmezett kapcsolatrendszer a hallássérült gyermekek integrált nevelésében, oktatásában. Fejlesztő pedagógia: Pedagógiai Szakfolyóirat 27, 2-3. 45 51., 
Mesterházi, Zs. (2002): Integrált nevelés a nemzetközi és a hazai oktatásrendszerben, Gyógypedagógiai Szemle 1, 10-13.

Mező, K., Mező, F. (2017): Fogyatékossággal élő gyermek a családban. In: Vargáné, Nagy A. (szerk.) Családi nevelés. Debrecen, Magyarország. Didakt Kft. 79-89.

N, Tóth Á. (2011): A jövő pedagógusai és az inkluzív nevelés, avagy hol tartunk hallgatóink integrált nevelésre való felkészítésében. Pedagógusképzés: pedagógusképzők és továbbképzök folyóirata, 3-4. 171-179.

Némethné Tóth Á. (2009): Tanári attitüdök és inkluzív nevelés. Magyar pedagógia 2, 105 120.

NET 1: Letöltés: 2018.09.14. Web: https://bit.ly/2TDeyqi.

Papp, G. (2002): Tanulásban akadályozott gyermekek iskolai integrációja a szakemberek közötti kooperáció tükrében. Magyar Pedagógia, 102. 2, 159-178.

Papp, G. (2004): Tanulásban akadályozott gyermekek a többségi általános iskolában. Comenius Bt., Pécs.

Papp, G., \& Schiffer, Cs.(2011): Az integrált és inkluzív nevelés hatása a pedagógusképzés egyes területein. Pedagógusképzés: pedagógusképzők és továbbképzők folyóirata 9, 3-4. 45-62.

Perlusz, A. (2013):Az integrált nevelés módszertani kérdései. In: Podráczky, J. (szerk.): Különlegesek: Adalékok a differenciálás módszertanához. Budapest, Magyarország: Bethlen Gábor Alapkezelö Zrt. pp. 73-102.

Réthy Endréné (2002): A speciáli szükségletü gyermekek nevelése, oktatása Európában. Az integráció és inklúzió elméleti és gyakorlati kérdései. Magyar Pedagógia 3, 281-300.

Réthy Endréné (2002): A speciális szükségletü gyermekek nevelése, oktatása Európában. Magyar Pedagógia, 102. 3, 281-300.

Réti, Cs. \& Csányi,Y. (1997): Gyakorló pedagógusok és leendő tanítók attitüdjeinek felmérése az integráció témájában. Gyógypedagógiai Szemle, 26. 2,81-89.

Tatár, A.,Lenténé, P.A.,Biró, M., Pucsok, J. M., Hidvégi, P. (2018.a): Észak-alföldi régió szolgáltatóinak hozzáférés biztosítása a speciális igénnyel élők számára.. In: Válogatott tanulmányok a sporttudományok köréböl. 1. Debreceni Egyetem Sporttudományi Koordinációs Intézet, Debrecen. 150-157.

Tatár, A.,Lenténé, P.A.,Biró, M., Pucsok, J. M., Hidvégi, P. (2018.b): Észak -alföldi régió akadálymentes turisztikai lehetőségei. Válogatott tanulmányok a sporttudományok köréből. Debreceni Egyetem Sporttudományi Koordinációs Intézet, Debrecen. 165-170..

UNESCO (1995): The Salamanca Statement and a Framework on Special Needs Education, Paris, UNESCO. 